\title{
ASSESSMENT AND PREDICTION OF NOISE LEVEL ON VARIOUS LINKS IN THE SURROUNDING AREAS OF AN UPCOMING AIRPORT IN INDIA
}

\author{
Arun Kumar Mishra ${ }^{1}$, Prabhat Srivastava ${ }^{2}$ \\ ${ }^{1}$ Assistant Professor, Civil Engg. Deptt M.M.M. Govt. Engg. College, Gorakhpur, U.P. India-273010 \\ arun_gmishra@yahoo.co.in \\ ${ }^{2}$ Professor \& Head, Civil Engg. Deptt, S.P.College of Engg, Bombay, India-400058, srivasp@gmail.com
}

\begin{abstract}
In scientific terms, noise (or sound) is a pressure oscillation in the air or water or any medium which conducts and travels (radiates) from the source. Due to increasing motorization, construction of roads, airports, flyovers and the growth in transport network, the noise level has exceeded the prescribed limit in many Indian cities. The main purpose of this study is to assess the impact and effect of noise emitted by vehicular traffic on the various links in the surrounding areas of an upcoming international airport at Navi-Mumbai ,India. This study presents on site noise level measurement at 10 locations situated at a distance of $10 \mathrm{Km}$. radius from the Airport reference Point (ARP) and also on the various links around the airport. Noise monitoring was carried out at all locations for 24 Hours (Leq) in residential, commercial, Industrial and silence zone located in the surrounding areas of Navi Mumbai (India) airport during November-February, 2009. FHWA model has been used for the prediction of noise level. The results show that noise pollution on various links are higher than the prescribed limits given by $C P C B$.
\end{abstract}

Key Words: Airport, Noise, FHWA Model, Navi Mumbai, Noise Pollution Index, Traffic Noise Index.

\section{INTRODUCTION}

Noise can be defined as an unwanted sound (Canter, 1996).Noise is one of the principle externalities of transportation specially air and road transportation and it mostly goes unpriced (Thangadurai et al, 2005) .The noise pollution produced by aircrafts during operations around airports represents serious social, ecological, technical and economic problem. The ability to assess and predict noise exposure accurately is an increasingly important factor in the design and implementation of any airport improvements. Aircrafts are complex noise sources. The number and intensity of noise sources vary with type of aircraft and, in particular, with the type of engines incorporated in their power plants. Relationship between the acoustic characteristics of the main noise sources and the flight mode parameters (or engine mode parameters) must be known for the best evaluation of noise levels under the flight path for any type of aircraft at any stage of its flight.

It has been estimated that around 20 percent of the European population from the noise level that are considered unacceptable (Nijland et. al. 2003).Environmental noise pollution has not been an entirely new phenomenon, but has been a problem that has grown steadily worse with time (Garg et al, 2007). Noise perceived as an environmental stressor and nuisance. Increasing noise level exposure is today a serious problem for most cities and high focus is put into monitoring and calculating actual noise exposure to understand the size of the actual problem (Bugliarello et al, 1976).

Noise is a prominent feature of the environment including noise from transport, aircrafts, industry and neighbors. Transport noise is an increasingly prominent feature of the urban environment making noise pollution an important environmental public health issue (Berglund and Lindvall, 1995).Noise pollution in urban cities is steadily increasing over the years (Ising and Krupa, 2004).This has direct and indirect impact to the people that can lead to the health hazard (Kryter, 1985).Some of the major health hazards cause by the noise are permanent hearing loss and psychological disorder (WHO, 1980).Other health problem may be high blood pressure, muscle tension, headache, migraine, irritability insomnia, (Haines et al, 2003). In India there were very few researchers on noise pollution being carried out. Even such surveys conducted in the past have revealed that noise level in urba areas are generally higher than the prescribed limit given by CPCB (Vidyasagar and Rao, 2006).

\section{TRAFFIC NOISE INDEX}

The major contribution to noise in the study area comes from vehicular traffic. Therefore, noise data is also used for finding Traffic Noise index (TNI). TNI is the A weighted sound level 
sampled at numerous discrete intervals over 24 hours study period. TNI is a weighted combination of L10 and L90. It describes the noise level and fluctuant characteristic. It has good relativity with subjective response of public and can be used to evaluate disturbance of a mass of traffic volume to public. Value of $74 \mathrm{~dB}(\mathrm{~A})$ is defined as threshold limit for where, L10 $=90$ per cent of the area under the histogram, L90 $=10$ per cent of the area under the histogram.

Table 1:.Index Range

\begin{tabular}{|c|l|c|}
\hline \multicolumn{1}{|c|}{ Grade } & Description & Index \\
\hline 1 & No & $<6$ \\
& noi & 0 \\
\hline 2 & Littl & $60-$ \\
& e & 67 \\
\hline 3 & N & $67-$ \\
& oi & 75 \\
\hline 4 & Rathe & $75-$ \\
& r & 100 \\
\hline 5 & Very & $>10$ \\
& nois & 0 \\
\hline
\end{tabular}

\section{AVERAGE NOISE LEVEL MATERIAL AND \\ METHODS}

Different receptor environment were monitored during daytime and night time and Leq values of each station have been calculated separately using the above equation for Leq. Average noise level of the project area during day time was calculated using the Equation as given below.

$\mathrm{Leq}_{\text {eq }}(\mathrm{D})=10 \log \left(10^{\mathrm{Leq}} \mathrm{I}(\mathrm{D}) / 10_{+}{ }_{10}^{\mathrm{LeqC}(\mathrm{D}) / 10_{+}}\right.$ $\left.10^{\operatorname{LeqR}(\mathrm{D}) / 10}+10^{\mathrm{LeqS}(\mathrm{D}) / 10}\right)$

where, LeqPa (D) is equivalent continuous sound level (average) during nighttime in the project area.

LeqI(D), LeqC(D), LeqR(D) and LeqS(D) are equivalent continuous sound level during daytime in industrial, commercial, residential and sensitive areas respectively

Similarly, average noise level of the project area during nighttime is also calculated .

\section{STUDY AREA}

The site of Navi Mumbai (India) airport is selected near Panvel town in an area admeasuring 2347 acres of land which is situated about $45 \mathrm{~km}$ away from the CBD of Mumbai/Santacruz airport. The airport is planned with two runways of $3700 \mathrm{M}$ with parallel taxiways designed to suit the outdoor noise level. TNI was calculated for daytime and nighttime period using the equation as given below.

TN

$$
=4\left(L_{10}-L_{90}\right)+L_{90}-30 \quad--
$$

new generation large aircraft. The other facilities include the domestic terminal, international terminal, cargo terminal, airfield lighting, city side facilities etc. The phase wise development approach has been adopted to suit the air travel demand.

The study area shown in Figure 1.0 covers the area around the airport falling within the radius of $10 \mathrm{~km}$. The study area is further divided in two parts namely core area and fringe area. The core area covers the area within the radius of $10 \mathrm{~km}$, in which all the scooped environmental parameters have been studied to understand the magnitude of impact. In the remaining area i.e. fringe area places of historical importance, aesthetics, cultural including environmentally sensitive have been studied

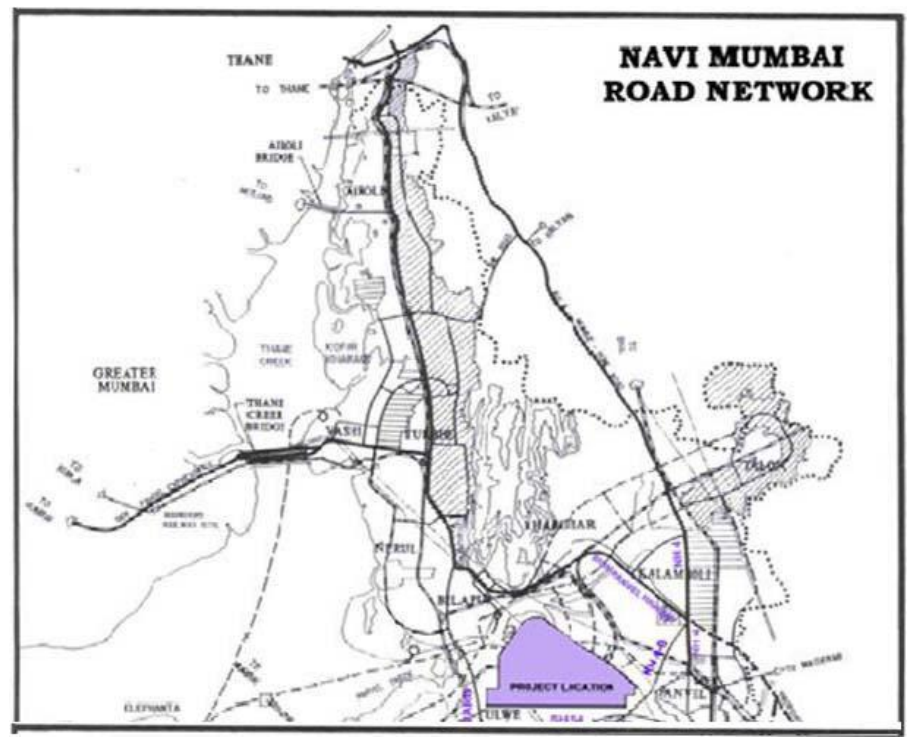

Figure 1: Study area along with Road Network Plan of NaviMumbai Region

\section{SELECTION OF MONITORING STATIONS AND NOISE LEVEL MEASUREMENT}

Noise quality monitoring stations were selected based on different noise generating sources and type of receptor environment in the project area. The list of sites selected for noise monitoring in the project area is given in Table 2. The noise equivalent level (Leq) was measured continuously at each monitoring sites using sound level meter Model ( LUTREN, SL-4001). The sound level meter was placed 1.2 to $1.5 \mathrm{~m}$ above ground level and at least $3 \mathrm{~m}$ away from sound reflecting sources like walls etc. in the outdoor environment. 
Measurements were taken for $24 \mathrm{hrs}$ at twelve locations during the month of January, 2009 (post monsoon season) to establish representative background (existing noise level).The Leq result of each location was statistically analyzed and the results were presented in table 3 in terms of average $L_{10,} L_{50}$ and $\mathrm{L}_{90}$ for different locations. Locations of noise monitoring stations are given in Figure 2.

Table 2: Ambient noise quality monitoring stations around the project area

\begin{tabular}{|c|l|l|}
\hline Sr.No. & Station Name & Category of area \\
\hline 1 & Ambuja Cement Limited & Industrial area \\
\hline 2 & CIDCO Bhavan, CBD Belapur & Commercial area \\
\hline 3 & Palaspa Junction & Commercial area \\
\hline 4 & Teen Tank Gavanphata & Commercial area \\
\hline 5 & Panvel CIDCO Office & $\begin{array}{l}\text { Residential Area (Mixed } \\
\text { category }\end{array}$ \\
\hline 6 & Kharghar Nodal Office & Residential Area \\
\hline 7 & Panchsheel Guest House & Residential Area \\
\hline 8 & Pargaon School & Sensitive area (Mixed category) \\
\hline 9 & MES School & Sensitive area(Mixed category) \\
\hline 10 & MGM Hospital, Kalamboli & Sensitive area(Mixed category) \\
\hline 11 & Swapna Nagri & $\begin{array}{l}\text { Residential Area (Mixed } \\
\text { category) }\end{array}$ \\
\hline 12 & Karnala Bird Sanctuary & Sensitive area \\
\hline
\end{tabular}

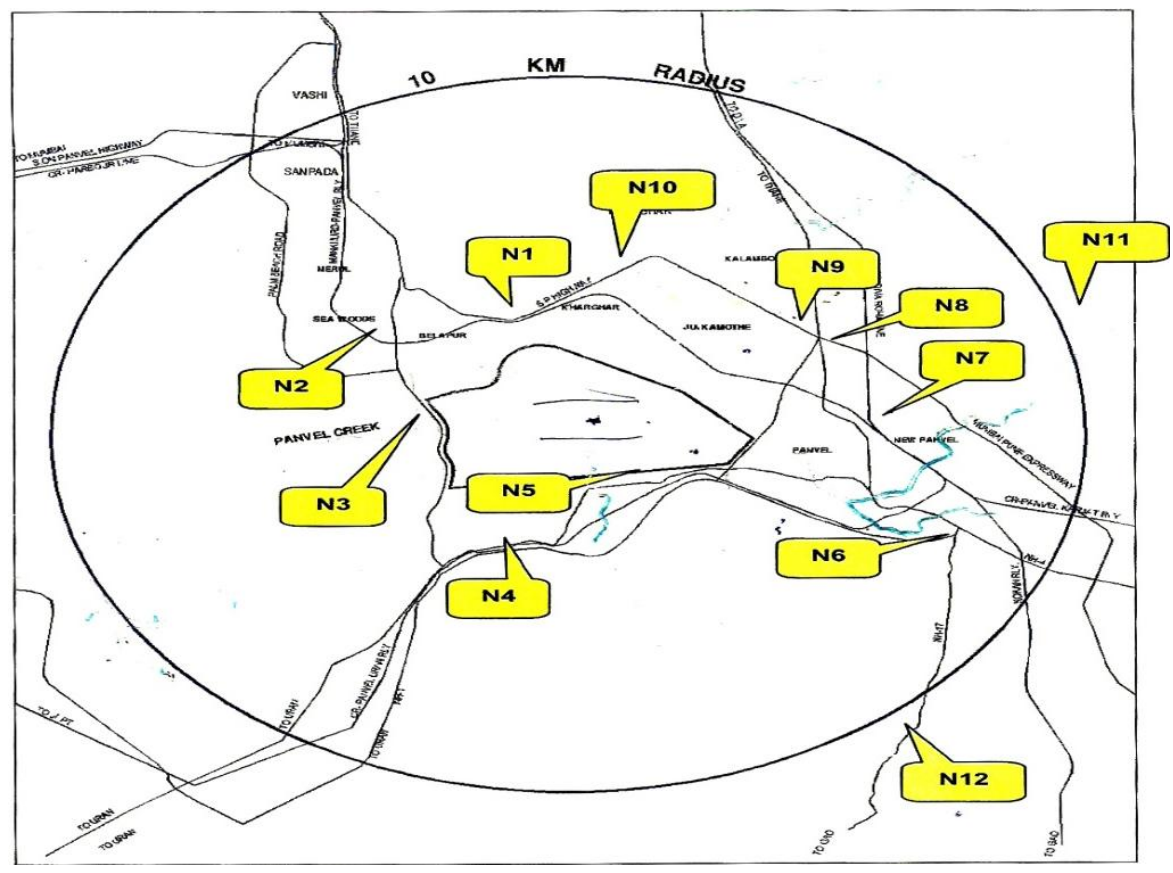

Figure 2: Plan showing Noise Monitoring station 
Table 3 Ambient Noise Level At Various Location Of The Project Area During Post Monsoon Season

\begin{tabular}{|c|c|c|c|c|c|c|c|c|c|}
\hline $\begin{array}{l}\text { Sr. } \\
\text { No. }\end{array}$ & Station & $\begin{array}{l}\mathrm{L}_{\mathrm{dn}} \\
\mathrm{dB}(\mathrm{A})\end{array}$ & $\begin{array}{l}L_{e q}(d) \\
d B(A)\end{array}$ & $\begin{array}{l}\mathrm{L}_{\mathrm{eq}}(\mathrm{n}) \\
\mathrm{dB}(\mathrm{A})\end{array}$ & $\begin{array}{c}L_{10} \\
d B(A)\end{array}$ & $\begin{array}{c}L_{50} \\
d B(A)\end{array}$ & $\begin{array}{c}\mathrm{L}_{90} \\
\mathrm{~dB}(\mathrm{~A})\end{array}$ & $\begin{array}{l}L_{\max } \\
\mathrm{dB}(\mathrm{A})\end{array}$ & $\begin{array}{l}L_{\min } \\
\mathrm{dB}(\mathrm{A})\end{array}$ \\
\hline \multicolumn{10}{|c|}{ Industrial Area } \\
\hline 1. & $\begin{array}{l}\text { Ambuja Cement } \\
\text { Limited }\end{array}$ & 66.0 & 61.6 & 59.2 & 61.7 & 57.7 & 53.8 & 75.0 & 49.8 \\
\hline \multicolumn{10}{|c|}{ Commercial Areas } \\
\hline 2. & CBD Belapur & 60.6 & 56.6 & 53.3 & 58.2 & 55.5 & 47.2 & 62.6 & 45.1 \\
\hline 3. & $\begin{array}{l}\text { Palaspa } \\
\text { Junction }\end{array}$ & 79.1 & 72.2 & 72.4 & 76.3 & 69.1 & 62.2 & 82.0 & 54.9 \\
\hline 4. & $\begin{array}{l}\text { Teen Tank } \\
\text { Gavanphata }\end{array}$ & 69.5 & 64.1 & 62.9 & 67.1 & 61.8 & 56.8 & 73.2 & 50.4 \\
\hline \multicolumn{10}{|c|}{ Residential Areas } \\
\hline 5. & $\begin{array}{l}\text { Panvel CIDCO } \\
\text { Office }\end{array}$ & 65.3 & 65.7 & 54.5 & 67.3 & 60.6 & 51.6 & 73.7 & 51.6 \\
\hline 6. & $\begin{array}{l}\text { Kharghar Nodal } \\
\text { office }\end{array}$ & 65.9 & 62.2 & 58.7 & 63.8 & 59.9 & 55.8 & 69.3 & 51.2 \\
\hline 7. & $\begin{array}{l}\text { Panchsheel } \\
\text { Guest House }\end{array}$ & 65.9 & 61.0 & 59.1 & 63.6 & 57.6 & 51.6 & 70.4 & 51.6 \\
\hline 8. & Swapna Nagri & 53.8 & 48.7 & 46.4 & 49.2 & 46.2 & 45.1 & 51.6 & 48.5 \\
\hline \multicolumn{10}{|c|}{ Sensitive Areas } \\
\hline 9. & Pargaon School & 69.6 & 71.0 & 56.0 & 71.1 & 60.7 & 52.2 & 82.4 & 47.8 \\
\hline 10. & $\begin{array}{l}\text { MES School, } \\
\text { New Panvel }\end{array}$ & 65.2 & 65.4 & 54.8 & 65.4 & 57.8 & 49.8 & 81.9 & 46.6 \\
\hline 11 & $\begin{array}{l}\text { MGM Hospital, } \\
\text { Kalamboli }\end{array}$ & 67.2 & 63.6 & 60.1 & 64.9 & 61.2 & 57.6 & 71.7 & 54.1 \\
\hline 12 & $\begin{array}{l}\text { Karnala Bird } \\
\text { Sanctuary }\end{array}$ & 55.3 & 49.5 & 48.7 & 51.8 & 48.7 & 44.3 & 56.5 & 40.5 \\
\hline
\end{tabular}

\section{NOISE MODELING}

Noise modeling for vehicular traffic

The impact on noise level due to project on communities in the adjoining area has been studied by Highway Noise Model
(FHWA Model) developed by the United States of America, department of Transportation engineering. In the present study noise prediction model calculates noise level through a series of adjustments to a reference sound level. The reference sound level is the energy mean emission level which is determined 
through the field measurements. Traffic noise prediction algorithm is of the following form. The value Leq is determined from the following equation

$\mathrm{L}_{\mathrm{eq}}=\mathrm{L}_{0}+\sum \mathrm{L}_{\mathrm{i}}$

$\mathrm{L}_{0}=$ Basic noise level for a particular stream of vehicles in $\mathrm{dBA}$

$\mathrm{L}_{\mathrm{i}}=$ Adjustment applied in $\mathrm{dBA}$

In the present study the various adjustments applied are volume and speed, distance and ground cover.

The combined effect of all categories of vehicle at the receptor has been determined by adding the individual values using the following equation

$$
\mathrm{L}_{\mathrm{eq}}(\mathrm{h}, \text { total })=10 \log \sum_{\mathrm{i}}^{\mathrm{n}} 10 * *\left(\mathrm{~L}_{\mathrm{eq}}(\mathrm{hi}) / 10\right)
$$

\section{Input to the Model}

\section{(A) Reference Noise}

Generation of noise significantly vary with vehicle speed. It is therefore necessary that speed dependency of noise emissions for various categories of vehicles is taken into account while using the model for noise prediction due to roadways. In this work, the speed wise relations presented by National Environmental Engineering Research Institute, (NEERI) India in their report on Environmental and Social Assessment for New Delhi, have been adopted. These are given in Table 4.0 an Table5.0

Table 4: Reference Noise Level Variation with vehicle speed and Category (Operative Speed $>30 \mathrm{~km} / \mathrm{hr}$ )

\begin{tabular}{|c|c|c|c|}
\hline Speed (kmph) & Cars & Trucks \& Buses & 2/3 Wheelers \\
\hline 30 & 56.0 & 73.0 & 58.0 \\
\hline 40 & 59.0 & 76.0 & 61.0 \\
\hline 50 & 63.0 & 80.0 & 66.0 \\
\hline 60 & 65.0 & 81.0 & 68.0 \\
\hline 70 & 68.0 & 81.5 & 70.0 \\
\hline 80 & 70.0 & 82.0 & 72.0 \\
\hline 90 & 72.0 & 83.0 & 74.0 \\
\hline 100 & 74.0 & 83.0 & 76.0 \\
\hline
\end{tabular}

Table 5: Reference Noise Level Variation with vehicle speed and Category (Operative Speed $<30 \mathrm{~km} / \mathrm{hr}$ )

\begin{tabular}{|c|c|c|c|}
\hline Speed (kmph) & Cars & Trucks \& Buses & 2/3 Wheelers \\
\hline 10 & 49.0 & 66.0 & 51.0 \\
\hline 15 & 51.0 & 68.0 & 53.0 \\
\hline 20 & 53.0 & 70.0 & 55.0 \\
\hline 25 & 55.0 & 72.0 & 57.0 \\
\hline
\end{tabular}

\section{(B) Traffic Volume}

Traffic volume count on different links ( NH-4, SH-4, Sion-Panvel Highway, Mumbai-Pune Expressway and Amra Marg) around the airport were carried out manually. Traffic volume forecasting was done according to growth rate of different links. Considering the total project period, the noise levels have been predicted during 2010, 2015, 2020, and 2025 and at the end of the project i.e. 2030. Data were organized according to model requirement.

Table 6 : Ambient noise quality standards (CPCB, India)

\begin{tabular}{|c|l|c|c|}
\hline \multirow{2}{*}{ Sr. No } & \multirow{2}{*}{ Category of Area } & \multicolumn{2}{|c|}{${\text { Limits in dB (A) } \mathbf{L}_{\mathbf{e q}}}$} \\
\cline { 3 - 4 } & & Day Time $^{\mathbf{b}}$ & 70 \\
\hline 1. & Industrial area & 75 & 55 \\
\hline 2. & Commercial area & 65 & 45 \\
\hline 3. & Residential area & 55 & 40 \\
\hline 4. & ${ }^{\mathrm{c}}$ Sensitive area & 50 & Night $^{\mathbf{c}}$ \\
\hline
\end{tabular}




\section{RESULT AND DISCUSSION}

Noise level at different links surrounding the airport were forecasted by Highway Noise model (FHWA Model) and predicted value of noise level at different receptor locations are shown in table 7 to table 11.

Table-7: Predicted Noise Level- Sion Panvel Highway

\begin{tabular}{|l|l|l|l|}
\hline Year & \multicolumn{3}{|c|}{$\begin{array}{c}\text { Leq (total) dBA } \\
\text { Distance (Meter) }\end{array}$} \\
\hline & $\mathrm{D}=15 \mathrm{M}$ & $\mathrm{D}=20 \mathrm{M}$ & $\mathrm{D}=30 \mathrm{M}$ \\
\hline 2010 & 83.84 & 82.59 & 80.83 \\
\hline 2015 & 85.42 & 84.51 & 82.41 \\
\hline 2020 & 86.95 & 85.69 & 83.94 \\
\hline 2025 & 88.47 & 87.23 & 85.46 \\
\hline 2030 & 90.01 & 88.76 & 86.99 \\
\hline
\end{tabular}

Table-8: Predicted Noise Level- Amra Marg

\begin{tabular}{|l|l|l|l|}
\hline Year & \multicolumn{3}{|c|}{$\begin{array}{c}\text { Leq (total) dBA } \\
\text { Distance (Meter) }\end{array}$} \\
\hline & $\mathrm{D}=15 \mathrm{M}$ & $\mathrm{D}=20 \mathrm{M}$ & $\mathrm{D}=30 \mathrm{M}$ \\
\hline 2010 & 79.81 & 78.57 & 76.80 \\
\hline 2015 & 81.50 & 80.25 & 78.49 \\
\hline 2020 & 82.72 & 81.47 & 79.71 \\
\hline 2025 & 83.69 & 82.44 & 80.68 \\
\hline 2030 & 84.66 & 83.41 & 81.65 \\
\hline
\end{tabular}

Table-9: Predicted Noise Level- National Highway No-4

\begin{tabular}{|l|l|l|l|}
\hline Year & \multicolumn{3}{|c|}{ Leq (total) dBA } \\
\hline & $\mathrm{D}=15 \mathrm{M}$ & $\mathrm{D}=20 \mathrm{M}$ & $\mathrm{D}=30 \mathrm{M}$ \\
\hline 2010 & 80.90 & 79.66 & 77.89 \\
\hline 2015 & 80.71 & 81.19 & 79.43 \\
\hline 2020 & 84.06 & 82.13 & 81.05 \\
\hline 2025 & 85.54 & 84.29 & 82.53 \\
\hline 2030 & 87.08 & 85.83 & 84.07 \\
\hline
\end{tabular}

Table-10: Predicted Noise Level- National Highway No-4B

\begin{tabular}{|l|l|l|l|}
\hline Year & \multicolumn{3}{|c|}{ Leq (total) dBA } \\
& & \multicolumn{3}{|c|}{ Distance (Meter) } \\
\hline & $\mathrm{D}=15 \mathrm{M}$ & $\mathrm{D}=20 \mathrm{M}$ & $\mathrm{D}=30 \mathrm{M}$ \\
\hline 2010 & 80.11 & 78.86 & 77.09 \\
\hline 2015 & 81.77 & 80.53 & 78.76 \\
\hline 2020 & 83.03 & 81.78 & 80.02 \\
\hline 2025 & 84.00 & 82.74 & 80.99 \\
\hline 2030 & 84.96 & 83.71 & 81.95 \\
\hline
\end{tabular}

Table-11 : Predicted Noise Level- State Highway No-54

\begin{tabular}{|l|l|l|l|}
\hline Year & \multicolumn{3}{|c|}{ Leq (total) dBA } \\
& \multicolumn{3}{|c|}{ Distance (Meter) } \\
\hline & $\mathrm{D}=15 \mathrm{M}$ & $\mathbf{D = 2 0} \mathbf{M}$ & $\mathrm{D}=30 \mathrm{M}$ \\
\hline 2010 & 77.84 & 76.59 & 74.83 \\
\hline 2015 & 79.49 & 78.24 & 76.48 \\
\hline 2020 & 80.74 & 79.49 & 77.73 \\
\hline 2025 & 81.72 & 80.47 & 78.71 \\
\hline 2030 & 82.71 & 81.46 & 79.69 \\
\hline
\end{tabular}




\section{CONCLUSION}

- Predicted noise level along the roadside of the various links varies between 74.83 and $90.01 \mathrm{~dB}$ which is more than the permissible limit given by the Central Pollution Control Board.

- Due to airport, increment in the noise level varies between $0.2 \mathrm{~dB}$ to $2 \mathrm{~dB}$ which is insignificant as compare to existing levels of noise.

- It is observed that operation of the airport is not likely to alter significantly the existing noise level.

- $\quad$ Noise level due to the vehicles required for servicing the aircraft and operation inside the airport is significantly less.

- Overall, airport is not going to bring out significant change in the noise quality except at few places on the links around the airport.

\section{ACKNOWLEDGEMENTS}

The authors are thankful to Dr Dhingra S. L. and Dr. A.K.Dixit , Professors, Civil Engineering Department, I.I.T. Bombay, India for their valuable guidance and suggestions

\section{REFERENCES:}

[1] Alexandre A., Bugliarello G Barnes J., and Wakstein C. 1976. The impact of noise pollution: A socio technological introduction. Pergamon Press Inc. New York . pp-212-232.

[2] Canter, L.W. 1991, Environmental Impact Assessment, McGraw Hill Book Company, International Edition. pp 419-437.

[3] Garg, N.K., et al., 2007, Noise Pollution and its impact on urban life. J. Environ. Res. And Develop.,2(1), 567576.

[4] FHWA (1978) "Highway Noise Measurements for Verification of Prediction Models" FHWA report, Washington.

[5] Haines, M.M., et al., 2003, Qualitative responses of children to environmental noise, Noise Health, 5, 1930 .

[6] Ising, H. and Kruppa B., 2004, Health effects caused by noise: evidence in the literature from the past 25 years, Noise Health, 6, 5-13.

[7] Kryter K.D.,(1985), The Effects of Noise on Man, $2^{\text {nd }}$ edn, Orlando, FL:Academic Press. pp 87-96

[8] Nijland, H.A. et al., 2003. Cost and Benefits of Noise Abatement Measures, Transport Policy, 10, 131-140.

[9] Thangadurai. N.,et al., 2005 Evaluation and Analysis of noise quality of Ambur, Tamil Nadu, India, Journal of Environmental Science and Engineering, 47, 7-12.

[10] WHO Report. 1980. Environmental Health Criteria of noise.

[11] Vidyasagar, T., and Rao, G.N. 2006. Noise Pollution Levels in Vishakhapatnam City(India). Journal of Environmental Science and Engineering, 48,139-142.

\section{BIOGRAPHIES:}

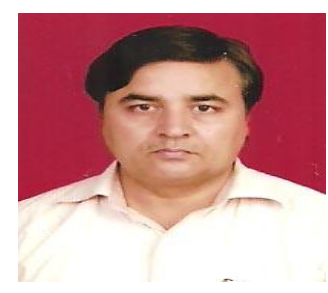

Arun Kumar Mishra,is a Assistant Professor in Civil Engg. Department, Madan Mohan Malviya Govt. Engg. College Gorakhpur, U.P .India 273010 (emailarun_gmishra@yahoo.co.in

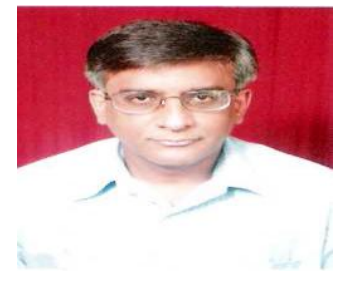

Prabhat Srivastava, is a Professor \& Head, Civil Engg. Department, S.P. Government College of Engg. Mumbai ,India-400058,(e-mailsrivasp@gmail.com) 